\title{
An identity of opposition against urban cosmopolitan setting in Yasmina Khadra's The attack (2006)
}

\author{
RETNO SUKARDAN MAMOTO
}

\begin{abstract}
ABSTR ACT
Yasmina Khadra, a female name, pseudonym of Muhammed Moulessehoul, an Algerian military officer for 25 years is now a French citizen. John Cullen translates The attack (2006) from French. Rosenau's post-modernist perspective places the Israel-Palestine conflict in a context of social gap. Israel, a First World, whereas Palestine Third World, are both in the Middle East region. Amin Jaafari and his wife, Sihem, a couple of Arab naturalized citizens of Israel, live in urban cosmopolitan city of Tel Aviv. Opposing Amin's success as a surgeon, Sihem is more attracted to fight for the Palestinian liberation for a homeland. Sihem camouflaged herself with prosthetic pregnancy, blew bombs in a Tel Aviv café, and died. McLeod's postcolonial point of view places Sihem as a hero. Woodward's concept of identity addresses the Jaafaris' troubled identity. Thus, opposition against urban cosmopolitan setting is the central theme as a notion of identity of that of the protagonists responding to their set situation.

KEYWORDS

Postmodernist, postcolonial, identity, conformity, opposition, urban cosmopolitan.
\end{abstract}

Most people agree with the idea of progress in the development of a society. It starts from rural and traditional life, and then it expands into a mercantile orientation. We address modernity when societies start to move into industrial and then last to adopt technological achievements. We assume that this thesis is what most people in the world like to have and put their best efforts to orient themselves stepping into living in a more complex institution of the society. Israel and Palestine are two countries of opposite social and

RETNO SUKARDAN MAMOTO is a senior lecturer at Fakultas Ilmu Pengetahuan Budaya (Faculty of Humanities) at the English Studies Program and the American Studies Graduate Program, Universitas Indonesia in Jakarta. She took her Ph.D. degree in American Studies at the University of Hawaii, USA, 1997 with the thesis U.S.-Indonesia relation 1953-1958 in four key print media, The New York Times, The Washington Post, The Wall Street Journal, Time. She has presented several papers in her subject field, among others: "Reading Asia through Salman Rushdie's Shalimar the clow" (Sanata Dharma University, Yogyakarta, 18 February 2009). E-mail: retnosmamoto@yahoo.com.

(C) 2009 Fakultas Ilmu Pengetahuan Budaya, Universitas Indonesia 
political settings. Yasmina Khadra in The attack (2006) presents a hard reality of a revelation that modernity is probably an empty jargon. What is more worthy for Palestinians living in ghettos in Jenin, in the West Bank than an independent sovereign nation that can stand equal with its closest neighbor country, Israel, eventually strengthens the need for a sense of meaning.

An Arab in Israel is definitely a minority. It is, therefore, a man like Amin Jaafari, who thought of improving his quality of life by becoming close to what "a decent citizen" could be. Social institutions, like schools and universities may function perfectly in educating the people of a society. Regardless of social and cultural differences that can happen in one's society, these institutions are agents of change. By his hard works, Amin is a representation of one who struggles successfully to be decent and a respected person in the society. As a practicing surgeon in a Tel Aviv hospital, Ichilov, he moves among his colleagues, who are mostly Jews. It is a common path for someone who was born in a rural town, and then found himself or herself successful in the city, despite the fact that ethnic difference is covered. This urban phenomenon hypothetically would be a guarantee to someone who lives in the city. Being decent, prosperous, and function socially are among the things that people who live in the city would like to commend themselves to achieve. A story of a successful surgeon like Amin Jaafari would seem to be a rightful representation of how one should direct one's life.

Sihem, on the opposite, does not condone the rightful path of her husband, Amin Jaafari. She represents the antithesis of this city-life idealism. Hiding behind her conformity to the life that her husband had offered to her, and that she was a naturalized Israeli citizen, she led her life to a secret allegiance to the liberation of the Palestinian people that even her husband was not aware. She has totally a different plan of what life should be. The double life that she has is in one side allowing herself to be recruited as a suicide bomber, an opposite against her husband concept of success; whereas, in the other, it is a totally different path from her husband's achievement as an urbanite, which is equal to what most people in the city would dream of having achieved. Suicide bombing for Sihem is a vocation, equal to the success of one who lives in the city and transforms his or her life into what one considers an achievement in the society. Either one conforms into what the mainstream society has dictated to his or her life, or that one lives in the opposite is of both social phenomena in an urban cosmopolitan society. In conclusion, one may encounter social as well as cultural problems in city life.

\section{THEORY}

Rosenau says, "Post-modernism in the Third World emphasizes the style of political participation over effectiveness" (Rosenau 1992: 155). Amin Jaafari and his wife, Sihem, the main characters in Khadra's The attack, lived in a political world where Palestine as a nation is fighting against Israel for its territorial sovereignty. It is more than an imperative for people who live under oppressing power, to define their existence in order to be a part of 
the world, either it is at the "inside" such as in the case of Amin, or at the "outside" like Sihem. Moreover, Rosenau continues to say, "Modern social and political movements in the Third World are giving way to new forms of political expression" (Rosenau 1992: 152). Amin conforms to the mainstream and separates himself from his original identity, as Arab from Jenin, Palestine. Sihem opposing to this form of conformity chooses to live up the transcendental idealism. Therefore, it is legitimacy for the action of Sihem to be a suicide bomber. On the other hand, it is conformity in the case of Amin by functioning in the social institution of the people who were supposed to be his enemy. In other words, both Sihem and Amin have reacted in a postmodernist way.

While exposing Sihem and Amin Jaafari in a post-modernist way of life, Israel to the Palestinians represents a dominating power. Thus, the political movement of Sihem in participating in the recruitment of suicide bombers is compatible to a "national liberation" movement that McLeod points out (McLeod 2000: 75). The Palestinians are justifiable in seeing themselves as oppressed. Furthermore, the ongoing conflict between Israel and Palestine in current contemporary setting speaks to a need of a people, who although modern, do not regard life as a mere status quo. The subservient status of Palestinians in general reflects an "anti-colonial" nationalism (McLeod 2000: 75), such as the case of the Palestinians, where they are "alienated from the land which is their rightful possession" (McLeod 2000: 75), their sense of justice claims the legality of bombing actions. In this context of post-colonialism, the Palestinians represented by Sihem are what Rosenau says as "the new form of political expression" (Rosenau 1992: 152).

The post-modernist choice of life, as well as the post-colonial context of the protagonists in Khadra's The attack sums up in the frame of identity. Woodward (1999: 1) mentions, "identities in the contemporary world derive from a multiplicity of sources - from nationality, ethnicity, social class, community, $[\ldots] "$. For these four characteristics, Sihem and Amin Jaafari have in common. In terms of nationality, despite their naturalization to being Israeli citizens, they are both Arabs, and so in terms of the larger society, their ethnicity is Arab. Social class as indication of where one belongs in a society, the Jaafaris have managed to be in the mainstream of the Israeli society. Although they are both respected citizens of Israel, the community where the Jaafaris live, that is in Tel Aviv, Israel, is not real. Amin has to assume a new identity in the community of the medical professionals and leaving behind the community of his ethnicity. On the other hand, Sihem maintains the tie of her ethnic identity by associating herself with the cause of the Palestinian liberation movement. When one is born, and raised, and live in the society, where he or she is part of, he or she is the insider in the community. Sihem's identity is to her Palestinian national and ethnic ties although she lives in the land of the oppressor, whereas Amin, her husband, cuts the bond of his nationality of origin and ethnicity, and resumes a new tie with the oppressor. The two protagonists that show a problem in their survival play this sort of 
"identity crisis" (Woodward 1999: 1). To sum up, The attack is a novel that can be discussed in these three perspectives, post-modernist, post-colonial, and identity.

\section{METHOD}

Khadra's The attack addresses life in two different worlds, Palestine and Israel, although they are both close to each other and exist in the same region, the Middle East. The method this paper uses is by comparing Amin Jaafari with his wife, Sihem, and contrasting Tel Aviv against Jenin, the former representing established urban contemporary setting, while the latter an antithesis of the former. In light of the three theories, post-modernism of Rosenau, McLeod's post-colonialism, and Woodward's theory of identity, the discussion in the paper is comparing Amin Jaafari with his wife, Sihem, as they both represent a different world, mindset and identity. One speaks for urban contemporary life, where, in this case, Amin, resumes a profession where he could function, and the other, Sihem, the wife, opposes the urban and contemporary life and remains attached to the "old world" of the Palestinian Arab. The urban contemporary life in Tel Aviv of Israel is contrasted to the cities where the Palestinians dwell, such as in the West Bank area, particularly in Bethlehem and Jenin, where most of the relatives of the Jaafaris live. The former world is modern whereas the latter is undeveloped and in chaos. As Amin resumes a new identity, and conforms to the world of the oppressor, Sihem keeps her Palestinian call; thus their identity is dilemmatic.

\section{DISCUSSION}

\section{THE POST-MODERNIST}

Life in a big city uses professionalism and dedication that needs one to "sacrifice" to be accepted. Doctor Amin Jaafari is an example of a picture of success in a setting of a Tel Aviv hospital, Ichilov. His achievement in surgery earned him a path to live in urban contemporary environment. Before he became a naturalized Israeli citizen, the dream of a young boy of twelve, a son of Bedouins, "to join the brotherhood of the highly educated elite" (Khadra 2006: 7) is "a sort of reflexive disgust" to his fellow compatriots. Imagine to place young Amin in a surroundings where "the other medical school graduates [...] were wealthy young Jews who wore chain bracelets and parked their convertibles in the hospital lot" (Khadra 2006: 7-8). His feeling of inferiority has made him aware of the gap that happens between the two races, Jew and Arab. "They looked down their noses at me and perceived each of my successes as a threat to their social standing" (Khadra 2006: 8). He admitted that he had to restrain himself to react against his foreign classmates "who had to bite their tongues a few times before they'd ask an Arab for a light" (Khadra 2006: 9). Even in the midst of a bom attack where it turned out that Sihem was the suicide bomber who blew a bom in Hakirya, Tel Aviv, an 
injured man rejected being examined by Doctor Jaafari. He shouted, "I don't want any Arab touching me. I'd rather croak" (Khadra 2006: 15). After the bombing, Amin had to rush home driving his car stopped by police officers. One of the officers refused to let him continue his ride. "He [...] calls his headquarters to verify my employment status and the information on my driver's license and professional ID card" (Khadra 2006: 21). The officer said on the phone, "He's an Arab, a naturalized Israeli citizen. He says he's just left the hospital, where he's a surgeon.[...] Jaafari, with two $a^{\prime}$ s.[...] Check with Ichilov. [...]" (Khadra 2006: 21). Here Amin, who has been "a brilliant student and a handsome lad" (Khadra 2006: 9), has stuffed all the difficulty that he experienced for being an Arab in an Israeli surrounding. He has managed to suppress his inferiority by excelling to be part of the oppressor society.

In his assumed social status, not only did he have to bury some of his feelings, especially in light of his social relationship with his colleagues, he also had to conform to the life that he had with his wife, that somehow he lose ground to be close to his wife, Sihem. A female physician friend of Amin, Kim Yehuda, said, "The tragedy of certain well-intentioned people [...] is that they don't have the courage of their commitments, and they fail to follow their ideas to their logical conclusion" (Khadra 2006: 10). Yehuda seems to grasp a sense of emptiness in the psyche of Amin as he could not be close to his wife. It seemed that Amin and his wife have a separate life, and that was what Yehuda senses of the relationship. Above all the life that Amin has managed to establish to be practicing surgeon in a Tel Aviv hospital has deprived him a sense of closeness to his spouse.

This side of Amin Jaafari's life that he has sacrificed so much apparently does not appeal to the attention of Sihem. The Jaafaris purchased a small house on the seashore, not far from Ashkelon (Khadra 2006: 11). They also had some "fairly substantial bank account" (Khadra 2006: 22). They also had summer vacation trips to "some fantastic place: Paris, Frankfort, Barcelona, Miami, and several Caribbean islands" (Khadra 2006: 22). They entertained people in their house and that they solicited to "many elegant parties" (Khadra 2006: 22). Amin "received several awards for [his] scientific research as well as for the quality of [his] work as a surgeon" (Khadra 2006: 22). They both had friends and "can count municipal dignitaries, civil and military authorities, and even a few stars of show business" (Khadra 2006: 22, 23). Despite the fulfilled life of an outstanding achievement of one with a profession as a surgeon that Amin could give to his wife, Sihem kept her unhappy past life and she remained in the "outside" of the mainstream, and had a life of her own.

Sihem leads her life that is very different from her husband's, that "every now and then she takes it into her head to prolong her visits to her grandmother. [...] Sihem adores the farm. [...] She likes to stay up late into the evening, atop a mound bathed by the tranquil light of the moon" (Khadra 2006: 21). Sihem seems to long for natural beauty that would compensate her past. After the bombing, when Amin was home coming back from the hospital wondering about his wife, he was trying to recollect his memory about his 
wife. "Her smile is as big as a rainbow, but it isn't matched by the look in her eyes. Life hasn't always been kind to her. When she was eighteen, her mother died of cancer, and her father was killed in a road accident a few years later. It took forever before she finally agreed to accept me as her husband. She was afraid that fate, which had already been so cruel to her, would return and deal her another blow. After more than a decade of married life, despite the love I lavish on her, she still fears for her happiness, convinced that the smallest thing would be enough to shatter it forever" (Khadra 2006: 22). Amin sensed that his wife somehow was not in the same mood with him, but he was buried in his path of success that he did not explore deeply in his wife's internal condition.

The difference of Amin Jaafari and his wife, Sihem, explains the postmodernist point of view that a conflict happens when there is a social gap. Amin stands for prosperity whereas Sihem, poverty and oppressed. A Palestinian leader of the movement who lived in Bethlehem, Abu Mukaum (Khadra 2006: 211), said to Amin about the Palestinians including Sihem "we are only the children of a ravaged, despised people, fighting with whatever means we can to recover our homeland and our dignity" (Khadra 2006: 158). Rather than assuming a new identity among the Israelis despite her being Israeli citizen, Sihem was more interested in assisting the liberation movement by allowing the Jaafari's residence to be a meeting place. Amin solicited his nephew, Adel, to inquire about Sihem's involvement with the movement. Adel said, "We held all our important meetings at your house. We disguised ourselves as plumbers or electricians and there with our equipment. We drove service vans so as not to arouse suspicion" (Khadra 2006: 221). Moreover Adel said, "Sihem put her bank account at our disposal - we would deposit money into it for the Cause. She was the keystone of our Tel Aviv section" (Khadra 2006: 221). Sihem was absorbed in the movement, the Intifada (Khadra 2006: 226). By keeping her political activity a secret from her husband, Sihem conducted a fund raise in Nazareth, where she had to solicit the movement's benefactors, and "assumed the responsibility of transporting the money to Tel Aviv" (Khadra 2006: 222). To defend the oppressed is what seems to attract Sihem more than following the footsteps of her husband, enjoying the luxury of urban cosmopolitan life. Instead of accepting her elevated social status in Tel Aviv and living comfortably, Sihem was preoccupied with the deprivation of the Arabs, who are literally neighbors of the Jews of Israel.

Jenin, the city of Amin's childhood, and where most of his relatives live, was gradually a depleting city. When he was a boy, his grandfather's compound had "Israeli bulldozers laying waste [...] in order to make way for a Jewish colony" (Khadra 2006: 236). In his personal quest to find a reason for his wife's death, Amin had to witness the chaos Jenin had become, a huge contrast of his domain back in the urban cosmopolitan Tel Aviv. "Boys are stoning the Israeli tanks and then scattering when the soldiers open fire: the whitish smoke of tear gas bombs spreads through narrow streets filled with dust; a crowd gathers around the body of someone who has just been shot 
down" (Khadra 2006: 206). Young people "throw themselves on tanks as [if] they were candy boxes" (Khadra 2006: 219). The militancy of the Palestinians has been a harsh expression of a commitment by the people to gain their territory back. Retaliating assaults by the Israelis have been matter-of-fact. Amin admitted that Jenin is a degenerate city, "mutilated by the multiple incursions of the Israeli army" (Khadra 2006: 209).

On his way to meet Khalil, another cousin of Amin took him by foot after driving his car and had to stop, as the rest of the main road was damaged. Khalil related the situation with the last ambush. "Sharon's soldiers have occupied a good part of the town and closed off the main roads. They wouldn't even let us get close to them because the car might be booby-trapped" (Khadra 2006: 202). In addition to that,

\begin{abstract}
"[a] whole blocks of houses have been knocked down by tanks and bulldozers, others destroyed by dynamite. The land where they stood is littered with mounds of earth and scrap iron, where colonies of rats have encamped, waiting to consolidate their empire. Rows of ruins line former streets; the crippled facades stand silent, covered with cracks and graffiti. And everything - the piles of rubbish, the carcasses of vehicles crushed by tanks, the bullet-riddled fences, the suspense-filled squares - everything evokes horrors [...]". (Khadra 2006: 203).
\end{abstract}

Contrast to Tel Aviv, Jenin is a city of war zone. Young men have equipped themselves with slingshots or rocket launchers and every day, there is enemy fire (Khadra 2006: 219). A life of chain fatalistic pursuit has become the mode of Jenin. A cousin of Amin, Wissam followed the path of Sihem by becoming a martyr. "He filled his car with explosives and drove into an Israeli checkpoint" (Khadra 2006: 247). As it has been the rule of the land imposed by the Israelis, after every bombing, it is not hard for the Israeli police to find the bomber, and immediate destruction of the residence is a command to obey. The Palestinians have to accept the reality of Israeli occupation. Faten, another cousin of Amin, says, "What's a house when you've lost a country?" (Khadra 2006: 248). It must have been a pathetic scene when people have to witness a demolition of a residential area. "The bulldozer bellows, spewing a thick cloud from its smokestack. As it pivots on itself, its steel tracks tear ferociously at the ground" (Khadra 2006: 248). Amin recollected about the incident, "one bulldozer was enough to reduce all eternity to dust in a few minutes" (Khadra 2006: 249). Amin best described the rationale of the crushed spirits of the inhabitants. Faten, his cousin, a thirty-five-year-old woman, was so brokenhearted that she finally joined the movement, and it was likely that she would choose to die as a martyr, following Sihem's act.

Ihab Hassan (in Cioffi) best expresses post-modernist point of view in light of the disorder that the modern world has become. The deteriorate existence of Jenin, that is caused by the Israeli expansion, sustains militancy. Hassan said that accordingly humanity suffers from "the illusion of both innocence and freedom". On one hand, while resuming a life of prosperity, Amin is both innocent and he is rightful to exercise his sense of freedom to pursuit 
his dream of success. At the same time, Sihem is also innocent in a way that she does not put her life in the midst of prosperity. However, the difference is that Sihem's conviction is the opposition and antithesis of a prosperous urban cosmopolitan setting. She remains in her world of chaos and celebrates to her ambition, and merges her life into a plan for oblivion. This choice is also in essence, an expression of freedom of being who she is, being a martyr for Palestinian cause. Innocence and freedom, as a result, accordingly, depend on the individual judgment, which the norms of the society play a part.

\section{THE POST-COLONIAL}

A city offers a certain ideal picture of promising better life. One thinks of living in the city in order to escape from poverty and humble living domain. The progress in a society is to develop itself from rural agricultural to modern industrial and technological environment. Tel Aviv in the coastal area in the northern part of Israel today is urban cosmopolitan. Jenin in Palestine, however, is the opposite. Its infrastructure is deteriorating as the people live in walled zones and under martial law as Israelis expand their habitat. Even in Bethlehem and Nazareth, the residential areas of Jews and Arabs are not the same. The former has more embellishment, whereas the latter is plain.

The Arabs in Israel live under the rules of the occupying government. The Middle East has brought one to think about the region where the Arabs, Jews, and others live. There have been centuries of history especially when we think about big religions in the world today. Judaism, Christianity, and Islam originate from this area. It is a status quo where the Palestine struggle for their liberation of their nation and fighting against the Israelis become imperative. In the case of Sihem, her sense of belonging to the Palestinian movement drives her to die as martyr.

McLeod says that, "individuals think they are part of a greater collective, that they share a 'deep, horizontal comradeship' with many others" (McLeod 2000: 69). Retrospectively, in light of post-modernist perspective, Sihem's choice of death is legitimate. The post-colonial viewpoint would lay Sihem in her relationship with her husband's cousins and the community where they are part. Sihem consciously integrated herself to the mode of the movement. Sihem was close to Adel as brother. There was not any lead that Sihem further her relationship with Adel. Amin was so furious thinking of Sihem might be unfaithful to him. To a man, who lives his life in urban cosmopolitan Tel Aviv, a run away wife leads him to think about betrayal. Amin was thinking that Sihem fell in love with his nephew. He was so relieved when Adel praised Sihem's piety as noble (Khadra 2006: 223). He said, "Sihem was a saint. An angel. I would have been damned just for looking at her too long" (Khadra 2006: 224). The merging of Sihem to a collective cause headed by a conviction of giving one's life to God shows how deep is the tie of brotherhood and a sense of collectiveness. The faith that Sihem shared with others in the community of patriots marks the shared belief of the community. Adel said, "Once you've chosen to give your life to God, that means you've renounced the things of 
this life, all earthly things without exception" (Khadra 2006: 224). In this case, Sihem's step for not sharing anything with her husband, especially about her activity, is a proof of her renouncing her 'earthly life without exception'. The surrender of Sihem to join in the resistance has turned out to be genuine.

The process of Sihem to be member of the community is gradual. The trust that has developed between Sihem and Adel is the foundation of cooperation between members of the movement. McLeod says, "These feelings of community are the emotive foundation for the organisation, administration and membership of the 'state', the political agency which enforces the social order of the nation" (McLeod 2000: 227). Adel admitted that in the beginning of the acquaintance, he did not trust Sihem, her nature and motive. In order to be under a strict organization, there was sort of initiation for Sihem in order to intrude herself in the mission of the "'state', the political agency which enforces the social order of the nation". Let us say that here, 'state' is Palestine where there is a collective mission to be accomplished. The movement is here is part of the Palestinian liberation, which is "the political agency". It is the instrument to achieve the goal, which is fighting for hegemony in the area. The "social order", of which Sihem was engaged to, is the quiet participation. Khalil, a cousin of Amin, best expresses the imperativeness of being recluse, at the time when he addressed Faten as well as Sihem, who were both surrendering to the voluntary death. He said, "no one has to account to anyone else. Everyone conducts his holy war the way he sees fit" (Khadra 2006: 251). Khalil refers to Faten when he says, "She's of age and perfectly free to do what she wants with her life. And with her death" (Khadra 2006: 251). He also mentions about Sihem's case, which is a common act for anybody in the community. "There aren't two weights and two measures [...]. If you agree to take up arms, you have to agree that others may do the same. Each of us has a right to share in the glory of battle" (Khadra 2006: 251). The bond among the members of the community involves some administrative contribution. Sihem shows her loyalty to her adherence to the movement, by keeping to herself the fact when she found out some documents and a handgun in a briefcase hidden under the bed. Adel admitted that he intended to slay Sihem, out of a sense of self protection, but he dismissed the plan at the time after the discovery, Sihem handed out to him a sum of money while she said, "That's for the Cause"(Khadra 2006: 225).

The preservation of the community goal is important for the survival of the idea of sacrifice for common good. This is a continuing ritual, where it is to remind the members of the community the valued act. Sheikh Marwan, the leader of the Intifada, held speeches in the Grand Mosque in Bethlehem and other cities and the people gathered around him listen to sermons. This is instruction to the congregation, which are those who are willing to participate in the warfare. The important lines of the Sheikh that touches the hearts of those who listen are:

"Is there a splendor so great as the Lord's face, my brothers? [...] And on the last day, when dust is all that shall remain of the earth, when all that shall remain of our 
illusions is the ruin of our souls, what answer shall we have to the question, What have you done with your life? [...] And on that day, my brothers, your fortunes, your relations, your allies, your supporters will give you no help.[ ...] In truth, my brothers, a man's riches are not what he possesses, but what he leaves behind him. And what do we possess, my brothers? What are we going to leave behind us? A homeland? What homeland? A history? What history? Some monuments? Where are they? By your ancestors, show them to me! Every day, we are dragged through the mud or before the courts. Every day, tanks roll over our feet, overturn our carts, smash our houses, and fire without warning on our children. Every day, the whole world witnesses our misfortunes [...]" (Khadra 2006: 117-118).

The lines emphasize a notion of transcending goal, so the people experience a sense of direction, strength, and unity to consider the 'life beyond' as a reality that is far more esteemed than all the miseries that are launched by the power of the enemy. The mode of existence in the opposite of urban contemporary setting, in light of postcolonial perspective, is a variant. The consequence of social environment is open to the reality of life each community, nation or country may lead. It can oppose to the general conception of living in urban contemporary world. In lieu with post-colonialism, the Palestinians carry their anti-colonial stand, justifying the dominant power, which is Israel subduing the Palestinians; therefore, the call for warfare is familiar to the members of the community.

\section{IDENTITY}

Regardless of the fact that Amin loves his wife so much, it does not say that Amin could completely be in command of his wife's aspiration. Another leader of the Intifada mocked Amin of his incapability to control his wife. He harshly made a remark,

\footnotetext{
"The good doctor has a grudge against us. His wife died because of us. But she was happy in her gilded cage, wasn't she? She ate well, slept well, enjoyed herself. She lacked nothing. And then, look, a bunch of metal cases turn her away from her happiness and send her to [...] how did you put it? [...] to "blow herself away'". (Khadra 2006: 212).

"Your wife chose her side. The happiness you offered her smell of decay. It repulsed her, you get it? She didn't want your happiness. She couldn't work on her suntan while her people were bent under the Zionist yoke". (Khadra 2006: 213).
}

The side that Sihem took is in accordance with the discourse of her fellow compatriots. She understood the struggle for Palestinian cause because of Israel's Zionism. The identification with the larger society drives Sihem into her own world, unpenetrable even by her husband. She leads a separate mindset very different from that of Amin's.

Sihem's identity is opposite to what her husband thought of her. As Amin was so confident of his fifteen-year marriage, providing his wife with a nice house, substantial financial account, but, however, Sihem was not as happy as Amin has considered of her. Adel, the cousin, said, 


\begin{abstract}
"You lived under the same roof and enjoyed the same privileges, but you weren't looking in the same direction. Sihem felt closer to her people than she did in your image of her. [...] She didn't hold a grudge against you for prizing so highly the honors you were showered with, but that wasn't the happiness she wanted to see in you; she found it a little indecent, a bit incongruous. It was as if you were firing up a barbecue in a burned-out yard. You saw only the barbecue, she saw the rest, the desolation all around, spoiling all delight. [...] Sihem didn't want your kind of happiness. She came to see it as morally questionable, and the only way for her to atone was to join the ranks of the Cause. It's a natural progression when you're the child of a suffering people". (Khadra 2006: 227).
\end{abstract}

The integration of Sihem to militancy is a development of an identity. Perhaps, it started when she felt alienated from her husband and the urban cosmopolitan world that she and her husband lived. Then it develops to attaching herself to the Cause because she has seen the need of it.

She blew herself so she could be meaningful to the community. She, more or less, shared with the common conception about the oppressed Palestinians, that "They'd like to be respectable, [...]; they'd like to be surgeons or pop singers or film actors, ride around in fine cars and live their dreams every day" (Khadra 2006: 219-220). Somehow, Sihem has a common understanding about the situation of the Palestinians that the community of patriots shares with each other. Adel expresses this. What he said to Amin, having a passport and going places, does not indicate freedom (Khadra 2006: 227). As Adel put his mind to Amin, he further said, "Having enough to eat isn't success" (Khadra 2006: 227). In other words, life is not just status, provision and a place to live, but it can be honorable and sacred. For Sihem, identifying her with the suffering compatriots, and willing to sacrifice her life have brought pride to her people.

By assuming a new identity, Sihem, is different from her husband, Amin. Woodward (1999: 10) mentions, "Identity is marked by difference". It either distinguishes wife from husband, it also collects a sense of collective. The Intifada is identical with the Palestinian liberation movement. That Sihem got married to Amin indicates that Amin has set a goal in order to live with a new identity. Amin and Sihem were supposed to uplift the new identity as urbanites, forgetting the original place and cutting off the tie with the family. They both sacrifice their originality. Amin, leaving behind his homeland and family, chooses to embrace the new identity that he has established through his professional achievement. The new society estranges him, because after all, he could not avoid giving the impression that he is Arab. Sihem, on the other hand, assimilated on the 'outside' with the new world, but her heart and soul remained in the old world of Palestine. She has led a double life, from the outside

"she was a woman of her time. She like to travel, she liked to swim, she liked sipping her lemonade on the terraces outside the shops, and she was too proud of her hair to hide it under a head scarf". (Khadra 2006: 156). 
However, in the inside, Sihem gave herself to the homeland, despite her outward appearance. She had sent a note to her husband before she committed the suicide. She said,

\footnotetext{
"What use is happiness when it's not shared, Amin, my love? My joys faded away every time yours didn't follow. You wanted children. I wanted to deserve them. No child is completely safe if it has no country. Don't hate me". (Khadra 2006: 68).
}

She sacrifices her life so the young generations of Palestine live with freedom. It is a statement of a new identity. By adopting this, Sihem is different from Amin. Nevertheless, being a woman does not hinder her intention to be militant.

In thriving for accepted identity, both Sihem and Amin found themselves at odd with the reality of their choice. The temporary link with the society of Tel Aviv was completely abrupt as soon as the neighbors who lived next door to the Jaafari residence found out the news of Amin's wife who loaded herself with explosives and went to a public place detonated the bomb. There was an outrage mob that threatened the life of Amin by literally harmed him with kicks and punches. The death of Sihem shows that finally, she had to separate herself from the bond with the husband as they got married and became naturalized. The plan to survive decently among the Israelis emphasizes more on the difference that the Jaafaris stand for against the dominant society. They are Arabs who live in a strange land of the Israeli, and finally, the unmasking of their camouflage revealed who they were. Although Sihem denounced her assumed identity, she would remain an example of heroism among her people. While Amin, maintained his identity as an Israeli citizen, he disintegrated himself. He died of a blast of an Israeli attack, which targeted Sheikh Marwan.

\section{CONCLUSION}

The impact of the Palestinian movement has influenced people around the world. An identity of opposition against urban contemporary world like that was carried by one of the novel's protagonist, Sihem, has happened in Indonesia in the last seven years. The incidents of suicide bombings that have occurred were such as, on 12 October 2002 bombs exploded in Paddy' Pub and Sari Club in Kuta, Bali; on 5 August 2003 at JW Marriott hotel, Jakarta; on 9 September 2004 at Australian Embassy, Jakarta, and on 1 October 2005 near a Jimbaran food court, and Raja's Restaurant at Kuta Town Square, Bali. The post-modernist perspective has viewed bombings enhanced through several methods legitimate. It is an expression of outrage; firstly, it is a sign of gap in the social environment, such as the case in the novel, Palestine, representing a chaotic place, antithesis to Israel, which is orderly and hegemonic, and secondly, it is a protest against Israel domination. In Indonesia, the objective somehow extends to a need to establish an Islamic hegemony in the region. The post-colonial view has placed Sihem in the place of martyr who represents 
a higher call in life. The crisis of identity that both protagonists suffer, leads to disintegration. The lesson we may draw from Yasmina Khadra's The attack is a complex problem exist in the midst of urban contemporary setting. While the Palestinian compatriots pursue their cause to regain their homeland in their own method, the rest of the world perceives the phenomenon perilous.

It is an important piece of information found in the book that talks about some current terminologies that are much heard in the media. There is a dialogue stating about the difference of activities related to Islam. Amin Jaafari was wondering if the wife has become an Islamist. The man who represents the Intifada movement says that the wife was not at all an Islamist. He said,

"An Islamist is a political activist. He has but one ambition to establish a theocratic state in his country and take full advantage of its sovereignty and its independence". (Khadra 2006: 157).

In Indonesia, a movement that has basic principle like the one described above is like the Darul Islam and Gerakan Aceh Merdeka. In addition to the category of an Islamist, the Intifada man in the book said,

"A fundamentalist is an extremist jihadi. He believes neither in the sovereignty of Muslim states nor in their autonomy. In his view, these are vassal states that will be called upon to dissolve themselves and form the one, sole Caliphate. The fundamentalist dreams of a single, indivisible umma, the great Muslim community that will extend from Indonesia to Morocco, and which, if it cannot convert the West to Islam, will subjugate or destroy it. (Khadra 2006: 157-158).

The man said that Sihem, like himself, was not neither an Islamist nor a fundamentalist, she and the compatriots, are Palestinian. He said,

"We are only the children of a ravaged, despised people, fighting with whatever means we can recover our homeland and our dignity. Nothing more, nothing less" (Khadra 2006: 158).

So, it is neither he nor Sihem apt to be called Islamist or fundamentalist. They both stand for the cause of the Palestinian liberation movement. He was sure that Sihem had the same ideal like himself. Moreover, different from the cause of the Palestinian liberation movement, the Intifada spokesman in the book mentions the crucial idea of the Islamic fundamentalism that needs to be accommodated, that is the establishment of "a single, indivisible umma or the great Muslim community that will extend from Indonesia to Morocco"(Khadra 2006: 157). Introspectively, the idea reflects the current movement in Indonesia such as expressed in the establishment of the N.I.I. or the Islamic Indonesian Nation.

In conclusion, encountering this mode of operation in urban cosmopolitan setting such as the existence of opposition movement as described in the novel and the real current suicide bombings such as those that happened 
in Indonesia, brings us into an awareness that urban contemporary setting has created consequences. Firstly, urban contemporary setting is inevitable because it is a result of development. Life in these surroundings brings a big social gap. Those, the privilege, have the power to sit on the mainstream position, supported by the system. The others, however, are the less privilege, displaced and poor. Indonesia's line of progress has a tendency of developing into urban contemporary surroundings. This might also enhance the addition to the less privilege, deprived of elementary and secondary education, and vocational schools, besides lacking of food resources. There is also a situation where education, food, and employment become minor, as objective of a higher call such as the Palestinian liberation movement as depicted in Khadra's novel, The attack, rises to the collective psyche of the people. And to complicate the meaning of life, call for militancy may also be on the rise.

Secondly, contrary to the antithesis phenomenon despite of social gap and displacement, urban contemporary setting can be advantageous. The service sectors could function to accommodate support institutions from the modest to the sophisticated level in the society. Efforts to establish consensus for the welfare of many, are best. This does not say that conflicts of interest will not occur. The role of leaders in the society who sit in various posts in the government and the private sectors, should be able to put aside causes that will divide communities, and work instead to encourage toward betterment.

\section{BIBLIOGR APHY}

Cioffi, Frank L. "Postmodernism: Etc.; An interview with Ihab Hassan interview", (http:// findarticles.com/P/articles/mi_m2242/is_1622_278/ ai_72986218), diakses 31 Juli 2007.

Khadra, Yasmina. 2006. The attack. Translated from the French by John Cullen. London: Vintage Books. (Original title L'attentat (Broché), 2005).

McLeod, John. 2000. Beginning postcolonialism. Manchester: Manchester University Press.

Rosenau, Pauline Marie. 1992. Post-modernism and the social sciences; Insights, inroads, and intrusions. Princeton, NJ: Princeton University Press.

Woodward, Kathryn (ed.). 1999. Identity and difference. London: Sage Publications. (Culture, Media, Identities Series). 